\title{
A Case Study for large-scale nearly zero energy retrofits of existing office building in Beijing
}

\author{
Fei $\mathrm{Lu}^{1,2, *}$, Yu Zou${ }^{1}$, Deyu $\mathrm{Sun}^{1}$, Biao Qiao ${ }^{1}, \mathrm{Ji} \mathrm{Li}^{1}$, Zhenyu $\mathrm{Yu}^{1,2}$, and Jianlin $\mathrm{Wu}^{1}$ \\ ${ }^{1}$ Institute of Building Environment and Energy, China Academy of Building Research, Beijing, China 100013 \\ ${ }^{2}$ Tsinghua University, Beijing, China 100084
}

\begin{abstract}
This paper studied the retrofit project of an existing office building in Beijing to meet the requirements of nearly zero energy buildings. The office building is the first retrofit nearly zero energy building project in China. There are technical difficulties under the constraints of the building and resources. In order to study the technical solutions applicable to the project, we analyzed the suitability of different energy-saving technologies based on the resources and characteristics of the project. Then we obtained the key energy-saving factors. This paper also discussed the energy saving effects of different energy efficiency technology solutions, proposing an optimized nearly zero energy technology solution and verifying the energy-saving level of the optimized plan. Compared with normal new constructions complied with national energy efficiency standard, the energy efficiency of this retrofit building increased by $60 \%$.
\end{abstract}

\section{Introduction}

Energy conservation is among the most critical issues faced by the sustainable development of human societies. Buildings account for over $40 \%$ of end-use energy in the world ${ }^{1}$.With the economic development, the energy consumption of office buildings is growing increasingly in China. The goal of building energy efficiency is to continuously improve building energy efficiency and move towards zero energy building. Nearly zero energy building (NZEB) is the major development target of many counties in the short to medium term, due to the technical and economical rationality. EPBD defined nearly zero energy building (NZEB) as buildings with a very high energy performance and where energy demand is nearly covered by energy from renewable sources ${ }^{2}$.

At present, NZEB requires $60 \%$ energy saving compared with normal new constructions complied with national energy efficiency standard in China. The existing buildings face challenges to achieve NZEB, as constrained by original architectural features and natural resources. Nearly zero energy for existing buildings involve two design strategies: minimizing the energy use through energy-efficient measures and adopting renewable energy to meet the remaining energy need. On the whole, there is no nearly zero energy retrofit projects of existing buildings in China. It is of great significance to explore retrofit scheme suitable for existing office building. In our work, the office building is the first retrofit nearly zero energy building project in China. The retrofit goal of existing office building is to meet the requirements of NZEB $\quad(60 \%$ energy-saving compared with new constructions complied with national energy efficiency standard in China). This study involves two major tasks: building design and energy system design, focusing on the main building retrofit components, energy-efficient

\footnotetext{
*Corresponding author: lufei_lufy@163.com
} 
technologies, building retrofit scheme optimization.

\section{Method and procedure}

\subsection{Retrofit objective and requirement}

The office building is the first retrofit nearly zero energy building project in China, which is proposed to apply for the NZEB demonstration project in Beijing. Compared with reference buildings that meet the requirements of the GB50189-2015 Design Standard for Energy Efficiency of Public Buildings, buildings with $60 \%$ energy saving are considered to be NZEB. Besides, the building airtightness is required to be not more than $0.6 \mathrm{~h}^{-1}$ under $50 \mathrm{~Pa}$ pressure difference. The requirements of key performance parameters are specified, details are shown in Table 1.

Table 1. Performance parameters of main components of NZEB in Beijing

\begin{tabular}{|c|c|c|}
\hline key components & Parameters & Indicator \\
\hline External wall & $\begin{array}{l}\text { Heat transfer coefficient } \\
\qquad \mathrm{W} /\left(\mathrm{m}^{2} \mathrm{~K}\right)\end{array}$ & $0.10 \sim 0.30$ \\
\hline Roof & $\begin{array}{l}\text { Heat transfer coefficient } \\
\qquad \mathrm{W} /\left(\mathrm{m}^{2} \mathrm{~K}\right)\end{array}$ & $0.10 \sim 0.20$ \\
\hline Ground & $\begin{array}{l}\text { Heat transfer coefficient } \\
\qquad \mathrm{W} /\left(\mathrm{m}^{2} \mathrm{~K}\right)\end{array}$ & $0.15 \sim 0.25$ \\
\hline \multirow{2}{*}{ Window } & $\begin{array}{l}\text { Heat transfer coefficient } \\
\qquad \mathrm{W} /\left(\mathrm{m}^{2} \mathrm{~K}\right)\end{array}$ & $\leq 1.0$ \\
\hline & SHGC & $\begin{array}{c}\text { Winter: } \quad \text { SHGC } \geq 0.45 \\
\text { Summer: } \quad \text { SHGC } \leq 0.30\end{array}$ \\
\hline \multirow{2}{*}{ Air heat recovery rate } & Total heat recovery rate $(\%)$ & $\geq 70 \%$ \\
\hline & Sensitive heat recovery rate $(\%)$ & $\geq 75 \%$ \\
\hline
\end{tabular}

\subsection{Design optimization}

The proposed approach integrates a comprehensive sensitivity analysis ${ }^{3}$ and iterative optimization for the optimal design of nearly zero energy retrofit. The procedure of nearly zero energy building design optimization of this paper is shown as Fig.1.

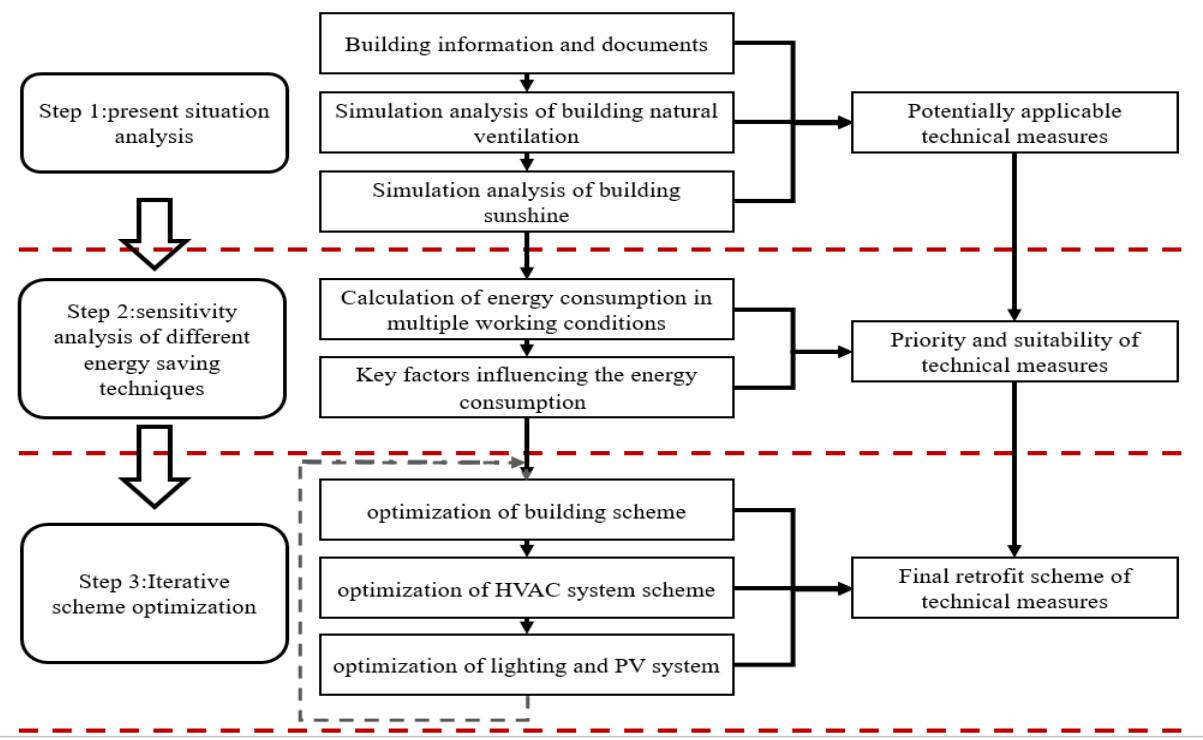

Fig.1. Procedures of NZEB design optimization

At first, the paper analyzes the current building situation including natural ventilation and sunshine. 
STREAM software is used to simulate the natural ventilation. We use software Ecotect to simulate sunshine condition to optimize the shading and lighting system. Considering the NZEB target and simulation results, we put forward preliminary retrofit suggestions. Then, we calculate the building energy consumption in multiple working condition through simulation software TRNSYS. The effects of different energyefficient technologies are also analyzed. Besides, a sensitivity analysis is conducted to identify the key design parameters for retrofit. Based on the key design parameters, we optimized the building envelope structure, shading, heat recovery system and natural ventilation. This project adopts energy-saving light system to reduce lighting energy consumption. Thirdly, we establish different cold and heat source model through TRNSYS to optimize the HVAC system scheme. In order to meet the goal of $60 \%$ energy-saving rate, PV energy system need to be integrated. Finally, we carry out iterative calculations, and form an optimized nearly zero energy retrofit scheme.

\section{Building present situation analysis}

\subsection{Building information}

The building was built at the end of the 20th century, and the three-dimensional view of the building is shown in Figure 2. The project is a 12-storey office building with a total floor area of $8651.9 \mathrm{~m}^{2}$, of which $7690 \mathrm{~m}^{2}$ are above ground and $961.9 \mathrm{~m}^{2}$ are underground. The building shape coefficient is 0.26 and the standard floor is 3.3 meters high. The original enclosure structure of this project adopts $100 \mathrm{~mm}$ thick aerated concrete wall. The doors, windows and other equipment are ordinary installed with poor heat transfer performance and air tightness. The building has only internal shading. Through the statistical analysis of the project, it is known that the window to wall ratio is relatively small, as shown in Table 2. The lighting system of the building is mainly composed of ordinary incandescent lamps and energy-saving lamps. The lighting system is manual controlled which has great energy saving potential. The density of building office workers is large, and there is many electrical equipment such as computers, printing and servers. At present, the building uses the municipal hot water provided by the heat exchange station of the park for heating in winter, and the chiller in the centralized machine room for cooling.

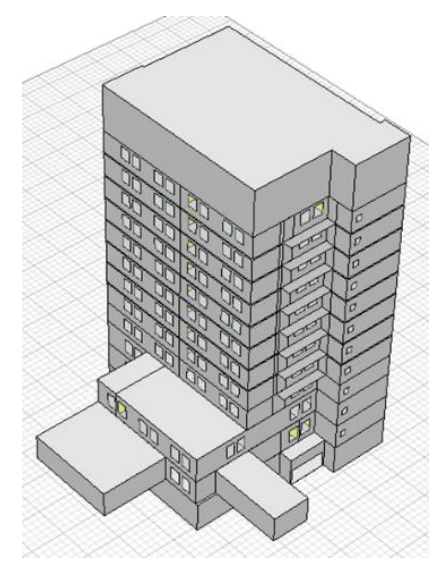

Fig. 2. Building model

Table.2. Window to wall ratio of the building

\begin{tabular}{|c|c|c|c|c|}
\hline $\begin{array}{c}\text { Outer window } \\
\text { orientation }\end{array}$ & east & west & south & North \\
\hline Window to wall ratio & 0.2 & 0.1 & 0.24 & 0.12 \\
\hline
\end{tabular}

In summary, the thermal insulation performance of the exterior wall, window and roof of this project is poor. The existing building has poor air tightness and no shading measures. Equipment performance and control levels of project energy systems and lighting systems need to be improved to reduce energy waste. In the design process of the building retrofit scheme, the factors that directly affect the building comfort and energy saving effect, such as building ventilation and sunshine shielding of surrounding buildings, should be taken into account.

\subsection{Natural ventilation simulation analysis}

The nearly zero energy building scheme ensures the natural ventilation effect of the building on the basis of reducing the window to wall ratio and reducing the heat loss in winter. Therefore, we use STREAM software to simulate the natural ventilation of the building. Through the natural ventilation simulation, the overall ventilation of the building openings can be analyzed. 

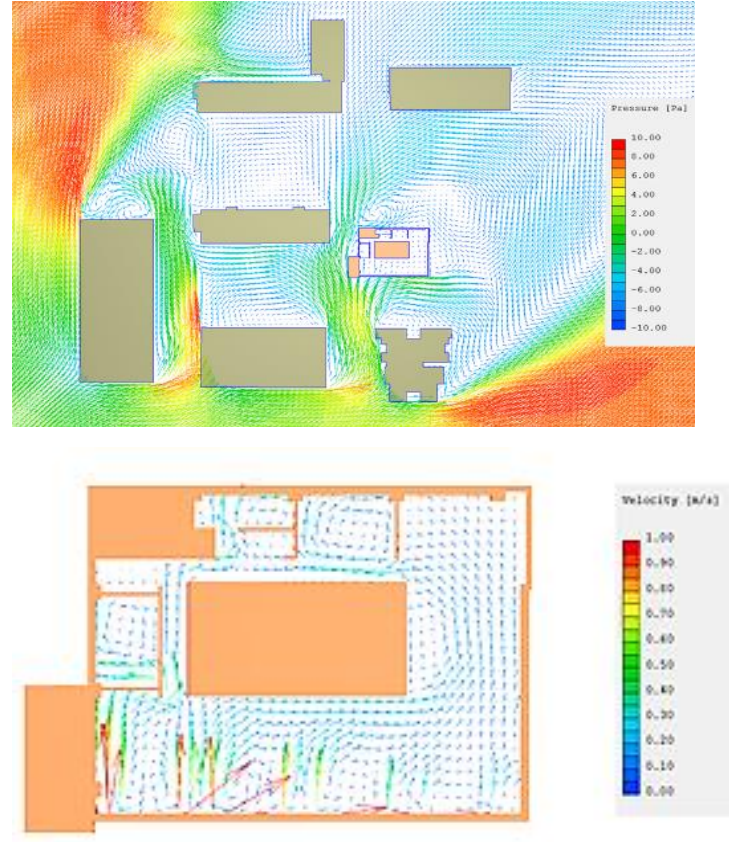

Fig. 3. Natural ventilation simulation results

According to the architectural design plan, 3F, 5F and $11 \mathrm{~F}$ are selected as typical floors to examine the natural ventilation of the room. In order to make the simulation calculation result as close as possible to the actual natural situation, the project should fully consider the influence of surrounding buildings. We establish the surrounding building model according to the general plan. The transition monsoon direction is set as southwest wind, and the average wind speed is $3 \mathrm{~m} / \mathrm{s}$ according to GB50736-2012 Design code for heating ventilation and air conditioning of civil buildings. This simulation takes into account the influence of surrounding buildings and adopts the method of indoor and outdoor joint solution, so it can simultaneously output outdoor results and indoor results.

For a clearer expression, the $5 \mathrm{~F}$ results are used to analyze the results of indoor key locations. As can be seen from the Figure 3, the outdoor wind speed is about $1.5 \mathrm{~m} / \mathrm{s}$.

The blocking effect caused by the high-rise building on the southwest side is obvious. Although the wind speed of the indoor air inlet is higher than $1 \mathrm{~m} / \mathrm{s}$, the wind speed of most indoor areas is about $0.1 \sim 0.3 \mathrm{~m} / \mathrm{s}$, which can basically ensure the indoor and outdoor natural ventilation effect during the transitional season. In the same way, we obtained that the indoor wind speed and wind pressure distribution of each main floor under the building opening scheme of the project are relatively uniform, which can basically meet the needs of natural ventilation. Therefore, the project can maintain the existing smaller window-to-wall ratio windows to reduce heat loss in winter.

\subsection{Sunshine analysis}

This report simulates the sunshine condition from 8:00 to 18:00 (June 22). The simulation results show the southward and westward areas have occlusion effect. There is no need to consider the sunshade in south direction of the first floor due to the occlusion effect. On the other floors, the sunshine hours are long. It is necessary to adopt building shading measures during the sunshine period.

\subsection{Suggestions on retrofit scheme}

This paper analyzes the current conditions of the building and. Combined with the simulation of building ventilation and sunshine and the nearly zero energy consumption requirement, the preliminary suggestions are as follows: (1) The original building envelope structure has a poor insulation effect. In order to comply with the relevant regulations of Beijing and reduce the noise pollution of the surrounding houses in the renovation work, the project use internal insulation and high-performance doors and windows. (2) The project can maintain the existing smaller window-to-wall ratio windows. (3) Using the appropriate shading measures and high efficiency LED system.

\section{Optimization of retrofit scheme}

\subsection{Sensitive analysis}

In this paper, parameter sensitivity of external wall heat transfer coefficient, roof heat transfer coefficient, ground heat transfer coefficient, external window heat transfer coefficient, shading, air heat recovery efficiency, natural ventilation, lighting system are analyzed. A total of 38 different working conditions were simulated and analyzed. Taking the roof heat transfer coefficient as an example, parameters and results under different working conditions are listed in 
Table 3. The influence of roof thermal performance on the cooling load and heating load is shown in Fig.4.

Table 3. The influence of roof thermal performance on the energy saving effect

\begin{tabular}{|c|c|c|c|c|}
\hline $\begin{array}{c}\text { Parameters } \\
\text { external wall heat } \\
\text { transfer coefficient } \mathrm{W} /\left(\mathrm{m}^{2} \cdot \mathrm{K}\right)\end{array}$ & Scenario 1 & Scenario 2 & Scenario 3 & Scenario 4 \\
\hline $\begin{array}{c}\text { roof heat transfer coefficient } \\
\mathrm{W} /(\mathrm{m} 2 \mathrm{~K})\end{array}$ & 0.21 & 0.21 & 0.21 & 0.21 \\
\hline $\begin{array}{c}\text { ground heat transfer coefficient } \\
\mathrm{W} /\left(\mathrm{m}^{2} \cdot \mathrm{K}\right)\end{array}$ & 0.16 & 0.16 & 0.16 & 0.16 \\
\hline $\begin{array}{c}\text { window heat transfer coefficient } \\
\mathrm{W} /\left(\mathrm{m}^{2} \cdot \mathrm{K}\right)\end{array}$ & 1.0 & 1.0 & 1.0 & 1.0 \\
\hline Shading coefficient in winter and summer & $0.35 / 0.55$ & $0.35 / 0.55$ & $0.35 / 0.55$ & $0.35 / 0.55$ \\
\hline Cumulative cooling load per unit area $\left(\mathrm{kWh} / \mathrm{m}^{2} \cdot \mathrm{a}\right)$ & 48.10 & 48.05 & 48.04 & 48.03 \\
\hline Cumulative heating load per unit area $\left(\mathrm{kWh} / \mathrm{m}^{2} \cdot \mathrm{a}\right)$ & -11.63 & -12.05 & -12.16 & -12.26 \\
\hline Change rate of cooling load $(\%)$ & $0.00 \%$ & $-0.11 \%$ & $-0.13 \%$ & $-0.14 \%$ \\
\hline Change rate of heating load $(\%)$ & $0.00 \%$ & $3.66 \%$ & $4.61 \%$ & $5.43 \%$ \\
\hline
\end{tabular}
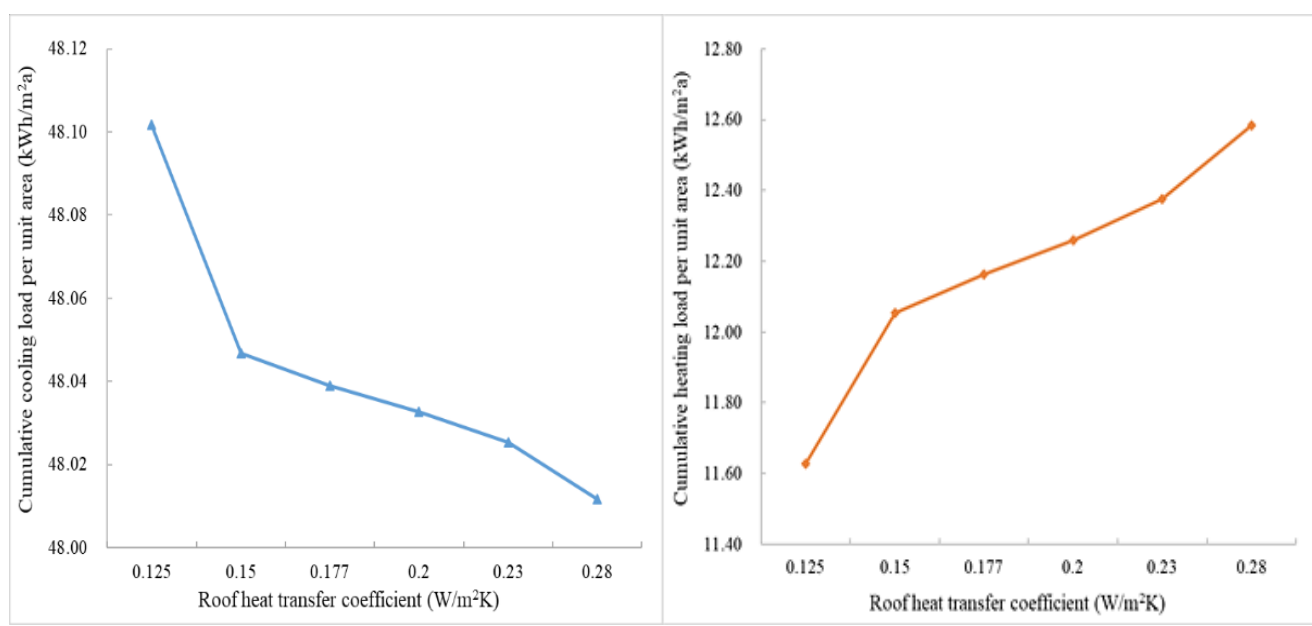

Fig. 4. Cumulative cooling and heating load per unit area

Based on the simulation and parameter sensitivity analysis, it can be seen that building envelope, building shading, air heat recovery efficiency and natural ventilation are key factors influencing the building energy consumption in Beijing China. Calculation of the building energy consumption under different status revealed that further reduction of energy consumption can be achieved by considering a number of suitable energy efficiency measures. According to the component parameter requirements of NZEB in Beijing and sensitivity analysis results, the preliminary retrofit plan is recommended as follows: (1) The project adopts internal thermal insulation transformation scheme. The heat transfer coefficient of the external wall reaches
$0.21 \mathrm{~W} /(\mathrm{m} 2 \mathrm{~K})$, the heat transfer coefficient of the roof reaches $0.125 \mathrm{~W} /(\mathrm{m} 2 \mathrm{~K})$, and the ground heat transfer coefficient reaches $0.16 \mathrm{~W} /(\mathrm{m} 2 \mathrm{~K})$. (2) The window uses a high-performance window with the $\mathrm{K}$ value of $1.0 \mathrm{~W} /(\mathrm{m} 2 \mathrm{~K})$ and SHGC of 0.45. (3) The external shading of the building can effectively reduce the cold demand of the building in summer, so the building is equipped with automatic adjustment of the external shading measures in the south, east and west directions. (4) The air heat recovery efficiency is increased to $75 \%$. (5) Natural ventilation is used to reduce building energy consumption during the transition period of the building. 


\subsection{Optimization of energy system}

According to the preliminary renovation proposal, the building energy efficiency has been greatly improved. In particular, the thermal performance improvement of the building envelope has a greater effect on reducing the winter heat load, and its cumulative heat load can be reduced by $30 \%$. In addition, building shading can effectively reduce cooling energy consumption. Increasing the efficiency of air heat recovery can reduce the heating demand. Moreover, natural ventilation during the transition season can achieve approximately $2-5 \%$ energy-saving. This paper calculated the energy consumption of the reference building and design building by TRNSYS software, with the building HVAC system and lighting system energy consumption converted into primary energy. According to the preliminary renovation plan, the energy saving rate is $40.17 \%$ compared with the reference building (Table 6 for detail parameters) that meets the energy-saving requirements of the GB50189-2015 Public Building Energy Efficiency Design Standard. To achieve the 60\% building energy saving goal, building cold and heat source, lighting system and renewable energy system need to be further optimized

\subsubsection{Cold source and heat source}

The retrofit building has a long use time and a high staff density. Furthermore, the cooling and heating demand of this building is much lower than others in the park. Therefore, we put forward the scheme setting up cold and heat source for the building separately. It is necessary to analyze the economics and energy consumption of different cold and heat source. The cold source includes screw chiller, magnetic suspension chiller and air source heat pump. The heat source is municipal heat or air source heat pump. We established the TRNSYS system model of different cold and heat source, and the simulation results are shown in the Table 4 and Table 5.

Table 4. Energy consumption simulation results of different cold sources

\begin{tabular}{|c|c|c|}
\hline Cold source & COP & $\begin{array}{c}\text { Cooling energy consumption } \\
\text { per unit area } \\
\mathrm{kWh} /(\mathrm{m} 2 \cdot \mathrm{a})\end{array}$ \\
\hline Screw chiller & 5.3 & 17.16 \\
\hline $\begin{array}{c}\text { Magnetic } \\
\text { suspension chiller }\end{array}$ & 9 & 11.9 \\
\hline $\begin{array}{c}\text { Air source heat } \\
\text { pump }\end{array}$ & 3.5 & 27.33 \\
\hline
\end{tabular}

Table 5. Energy consumption simulation results of different heat sources

\begin{tabular}{|c|c|c|}
\hline Heat source & $\begin{array}{c}\text { EE } \\
\text { R }\end{array}$ & $\begin{array}{c}\text { Heating energy consumption per } \\
\text { unit area } \\
\mathrm{kWh} /\left(\mathrm{m}^{2} \cdot \mathrm{a}\right)\end{array}$ \\
\hline Municipal heat & & 8.36 \\
\hline $\begin{array}{c}\text { Air source heat } \\
\text { pump }\end{array}$ & 2.5 & 6.75 \\
\hline
\end{tabular}

Compared with the municipal thermal scheme, the air source heat pump has slightly improved the heating energy efficiency. The NZEB has a large heating area but a small heating demand. Consequently, the operation cost of municipal heating is high with the basic fee of RMB18 $/ \mathrm{m}^{2}$ and the metering fee of RMB69.6 yuan/GJ. Therefore, air source heat pump is recommended to meet all winter heat load of the building. The energy-saving effect of the magnetic levitation chiller is the highest in the cold source, followed by the efficiency of the screw chiller, and the energy-saving efficiency of the air source heat pump is low. However, air source heat pump is recommended to meet the demand of building cooling load due to the high investment of magnetic levitation chiller. Finally, it is proposed to use a high-efficiency air source heat pump system as cold and heat source to meet all the cooling and heating requirements.

\subsubsection{PV system and intelligent lighting system}

As a renewable energy source, solar photovoltaic system is an important measure to supplement the energy saving of buildings in this project. In this section, three types of photovoltaic modules are examined and solar absorption cooling system is sized to satisfy the building energy demands. Transient simulation (TRNSYS) program is employed to simulate the 
performance of solar energy systems to determine the optimum parameters. The project plans to use a rooftop solar photovoltaic system to generate electricity from the building lighting system using renewable energy. It is planned to arrange $400 \mathrm{~m}^{2}$ photovoltaic panel on the building roof. According to the meteorological conditions in Beijing, the annual power generation is estimated to be about $66,014 \mathrm{kWh}$.

This project plans to ensure the $4-6.5 \mathrm{~W} / \mathrm{m} 2$ lighting power density of the building with intelligent LED energy-saving lamps. Intelligent lighting system covers the main functional areas of the building, excluding the machine room. Different areas can clarify the control accuracy and range of intelligent lights according to specific functional requirements. The scheme is based on energy-saving lamps and intelligent control lighting systems. And grouping control measures are adopted according to the building usage and natural lighting conditions.

\subsection{Iterative scheme optimization}

Considering the basic conditions of the project and the requirements of NZEB, this paper determines the building and energy system optimization scheme: using high-performance envelope structure, external window shading, improving heat recovery efficiency, making full use of natural ventilation, using air source heat pump, intelligent lighting system and roof photovoltaic system. We optimized the retrofit scheme to achieve $60 \%$ energy-saving rate through iterative calculation of different schemes. The energy-saving effect of the final retrofit scheme is calculated and analyzed, as shown in Table 6.

Table 6. Result of the final retrofit scheme

\begin{tabular}{|c|c|c|}
\hline Parameters & Reference building & Retrofit building \\
\hline ground heat transfer coefficient $\mathrm{W} /\left(\mathrm{m}^{2} \cdot \mathrm{K}\right)$ & 1.2 & 0.16 \\
\hline roof heat transfer coefficient $\mathrm{W} /(\mathrm{m} 2 \mathrm{~K})$ & 0.45 & 0.125 \\
\hline external wall heat transfer coefficient $\mathrm{W} /(\mathrm{m} 2 \mathrm{~K})$ & 0.50 & 0.21 \\
\hline window heat transfer coefficient $\mathrm{W} /\left(\mathrm{m}^{2} \cdot \mathrm{K}\right)$ & 2.7 & 1.0 \\
\hline SHGC & 0.52 & 0.45 \\
\hline Air heat recovery rate $(\%)$ & No & $75 \%$ \\
\hline Natural ventilation & No & Yes \\
\hline Sunshade & No & $\begin{array}{l}\text { Active external } \\
\text { shading }\end{array}$ \\
\hline Energy system & Chiller + boiler & Air source heat pump \\
\hline Intelligent lighting system & No & Yes \\
\hline PV system & No & Roof $400 \mathrm{~m}^{2}$ \\
\hline Energy consumption for heating $(\mathrm{kWh} / \mathrm{m} 2 \cdot \mathrm{a})$ & 50.76 & 2.37 \\
\hline Energy consumption for cooling $(\mathrm{kWh} / \mathrm{m} 2 \cdot \mathrm{a})$ & 10.86 & 9.59 \\
\hline $\begin{array}{l}\text { Energy Consumption of Transmission and Distribution } \\
\qquad \text { System }(\mathrm{kWh} / \mathrm{m} 2 \cdot \mathrm{a})\end{array}$ & 13.47 & 6.05 \\
\hline Energy Consumption of lighting System $(\mathrm{kWh} / \mathrm{m} 2 \cdot \mathrm{a})$ & 25.81 & 12.65 \\
\hline $\mathrm{PV}$ power generation $(\mathrm{kWh} / \mathrm{m} 2 \cdot \mathrm{a})$ & 0.00 & 6.20 \\
\hline Annual primary energy consumption $(\mathrm{kWh} / \mathrm{m} 2 \cdot \mathrm{a})$ & 195.68 & 70.69 \\
\hline Energy-saving rate $(\%)$ & & $63.87 \%$ \\
\hline
\end{tabular}


equipment, natural ventilation and sunshine conditions. Then we give the preliminary retrofit proposal based on the building characteristics. Secondly, based on energy simulation software-TRNSYS and sensitivity analysis method, we studied the key energy-efficient technologies of the building. Thirdly, we optimized the retrofit scheme through iterative calculation of different schemes. Finally, this study proposed a NZEB retrofit scheme, achieving $60 \%$ energy-saving rate compared with normal new constructions complied with national energy efficiency standard.

The study indicate that existing buildings can be converted into NZEBs in many ways and the decision may depend on the investment required for the retrofit. It is necessary to make specific analysis according to the building characteristics in the actual work.

\section{Acknowledgements}

This work is funded by the Research on the Definition and Technical Criteria of Nearly Zero Energy Building program under number 2017YFC0702602, which is one of the National Key Research and
Development Programs in China.

\section{Reference}

1. International Energy Agency, Key World Energy Statistics, (2017)

2. Ministry of Construction of the PRC, Design standard for energy efficiency of public buildings, China architecture \& building press, (2015)

3. Yu JH, Tian LW, Yang CZ, Xu XH, Wang JB, Sensitivity analysis of energy performance for highrise residential envelope in hot summer and cold winter zone of China, Energy and Buildings, 64 (2013)

4. Huang, Jianen, et al. Thermal properties optimization of envelope in energy-saving renovation of existing public buildings, Energy and Buildings 75(2014)

5. Ouyang, Jinlong, J. Ge, and K. Hokao. Economic analysis of energy-saving renovation measures for urban existing residential buildings in China based on thermal simulation and site investigation, Energy Policy 37(2009) 